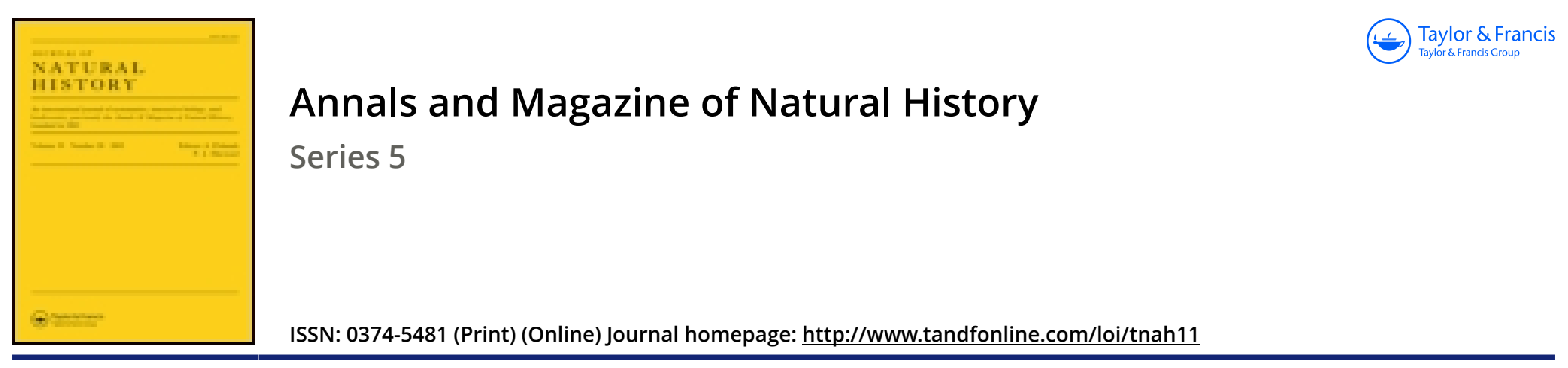

\title{
Anatomy and histology of the salivary glands in the Cephalopoda
}

\section{M.L. Joubin}

To cite this article: M.L. Joubin (1887) Anatomy and histology of the salivary glands in the Cephalopoda, Annals and Magazine of Natural History, 20:117, 251-252, DOI: 10.1080/00222938709460048

To link to this article: http://dx.doi.org/10.1080/00222938709460048

$$
\text { 曲 Published online: } 07 \text { Oct } 2009 .
$$

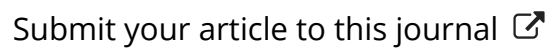

Џ Article views: 2 
striated. Forehead and vertex shagreened. Thorax moderately shining. Mesonotum nearly naked, only beset with a few short grey hairs, finely but distinctly wrinkled, the wrinkles forming very regular quadrangular cells. Scutellum with no median longitudinal furrow, at the base with two large pits, in its anterior half with the same sculpture as the mesonotum. Wings hyaline, fringed, with a radial area open on the outer margin, and with a distinct areola. Legs reddish yellow; apical joint of the tarsi and base of the trochanters black. Abdomen very shining, quite black."

Length of the female $2 \cdot 1-2 \cdot 2$ millim.

Verhandl. z0ol.-6ot. Gesellschaft in Wien, 1887, p. 205.

\section{Anatomy and Histology of the Salivary Glands in the Cephalopoda.} By M. L. Joubin.

The existence in the Octopod Cephalopods of two pairs of salivary glands has been long lnown-one situated in the abdominal cavity, the other close to the buccal bulb, the latter being deficient in the Decapods. The author has, however, ascertained the presence of the second pair in the latter, but it is fused into a single, median, unpaired gland, situated beneath the csophagus, and intimately mixed with muscular bundles. This gland, by its structure and the position of its excretory gland, is the homologue of the bulbar glands of the Ootopods.

In the Poulpe (Octopus vulgaris) M. Livon has recognized the existence of a gland lining one of the surfaces of the tongue, but be could not find its excretory duct. The author has found this gland in all the Cephalopoda cxamined by him; it consists of a sort of sheet of acini, all opening into the space which separates the tongue from the mandible and forms part of the buccal cavity. This explains why $\mathbf{M}$. Livon could not find any excretory duct.

Among the Octopods (Octopus, Eledone, Aryonauta) the extrabulbar salivary glands are situated in large lacunæ, into which the blood flows through very slender arteries, starting very symmetrically from the first division of the aorta by a single trunk on each side. This divides almost inmediately into two branches, of which the superior traverses the head and runs to the pair of bulbar glands, while the inferior one descends vertically to the abdominal pair. The blood which they convey becomes diffused between the glandular elements, reaches the periphery, and falls into the great sinus by a multitude of pores, which are tho intervals of the superficial acini or of the glandular tubes in the case of the abdominal gland.

In the Decapods (Sepia, Loligo, Sepiola, Rossia) they are not bathed in the blood-sinus, but the blood which has traversed them is collected by a venous network which unites with the great vein. The arteries are larger than in the Octopods, but their arrangement is less constant.

Sections of the glands taken from the living animal and vory carefully prepared with osmic acid showed that in all Cephalopoda 
the lingual gland, the unpaired subcesophageal gland of the Decapods, and the extra-bulbar pair of the Octopods are constructed upon the same type; they are bunches of acini formed by rather short cylindrical cells, filled in their inferior third with protoplasm with a large nucleus; the protoplasm is continued as a network in the middle third, and the rest is filled with rather large granules, which stain strongly. They much resemble the serous cells of Vertebrates. On the other hand, the pair of abdominal glands consist of large conical cells, the narrow lower part of which contains protoplasm, while the upper two thirds are filled with large balls of mueus, which does not stain with tho same reagents as the inferior third; these large caliciform cells emit through their wide apertures the balls of muens which become fused into a uniform mass in the excretory ducts, showing a remarkable analogy with the mucous cells of the higher Vertebrata.

The above is the fundamental structure of the salivary elements, but their arrangement differs greatly in the two great divisions of the Cephalopoda. In the Decapods the abdominal gland is small and formed of acini, like the other glands; but in the Octopods it is very large, and it is a tubular gland which may be broken up by the action of chloride of gold. It is formed by a tube indefinitely divided dichotomously, nearly equal in diameter throughout its whole extent, except in the final branches, which are smaller. The terminal tubular branches are clothed with a single layer of muscular fibres forming very regular and well-marked rings, the action of which is clearly to drive the mucus towards the excretory duct. All the tubes are twisted together inextricably, the spaces between them being occupied by connective fibres, large stellate colls, or free spaces through which the blood circulates.

The author adds that he has investigated the embryogeny of these glands and completed the researches of Bobretzky in many points.-Comptes Rendus, July 18, 1887, p. 17\%.

\section{Habitat of Peripatus Leuckarti. By Prof. F. Jefrrey Belz.}

Dr. E. P. Ramsay, F.R.S.E., has lately been so kind as to send me two specimens of Peripatus Leuckarti, Sänger. Prof. Leuckart's only information with regard to the place of origin of his specimen was "Neu Holland." It may therefore be of interest to state that Mr. Ramsay's examples were taken in the Queensland Scrubs, near Wide Bay. Sänger's paper being almost inaccessible, and, moreover, being written in Russian, I am glad to be able to add that Mr. Adam Sedgwick, F.R.S., will incorporate observations on the specimens sent me by Mr. Ramsay in his forthcoming monograph on the genus. Now that Mr. Ramsay has led the way, it is to be hoped more specimens of Peripatus may be sent from Australia to this country. 